DEMOGRAPHIC RESEARCH

VOLUME 35, ARTICLE 27, PAGES 783-812

PUBLISHED 21 SEPTEMBER 2016

http://www.demographic-research.org/Volumes/Vol35/27/

DOI: 10.4054/DemRes.2016.35.27

Research Article

\title{
A matter of norms: Family background, religion, and generational change in the diffusion of first union breakdown among French-speaking Quebeckers
}

\section{Benoît Laplante}

This publication is part of the Special Collection on "Separation, Divorce, Repartnering, and Remarriage around the World,” organized by Guest Editors Andrew Cherlin and Benoît Laplante.

\section{(C)2016 Benoît Laplante.}

This open-access work is published under the terms of the Creative Commons Attribution NonCommercial License 2.0 Germany, which permits use, reproduction \& distribution in any medium for non-commercial purposes, provided the original author(s) and source are given credit. See http:// creativecommons.org/licenses/by-nc/2.0/de/ 


\section{Contents}

$1 \quad$ Context and objectives $\quad 784$

$2 \quad$ Normative change in Quebec $\quad 785$

$\begin{array}{lll}3 & \text { Previous research } & 787\end{array}$

$\begin{array}{lll}3.1 & \text { Intergenerational transmission } & 787\end{array}$

$\begin{array}{lll}3.2 & \text { Religion } & 788\end{array}$

3.3 Education 789

$\begin{array}{lll}3.4 & \text { Research on union breakdown in Canada } & 790\end{array}$

$4 \quad$ Hypotheses $\quad 791$

$5 \quad$ Data and variables $\quad 791$

6 Method 793

$\begin{array}{lll}7 & \text { Results } & 795\end{array}$

8 Discussion $\quad 804$

9 Conclusion $\quad 804$

10 Acknowledgments 805

$\begin{array}{ll}\text { References } & 806\end{array}$

$\begin{array}{ll}\text { Appendix } & 811\end{array}$ 


\title{
A matter of norms: Family background, religion, and generational change in the diffusion of first union breakdown among French-speaking Quebeckers
}

\author{
Benoît Laplante ${ }^{1}$
}

\begin{abstract}
BACKGROUND

Previous research conducted in societies where unmarried cohabitation remains limited suggests that having grown up with unmarried parents fosters marital instability. There is little research on this relationship in societies where unmarried cohabitation has become common.
\end{abstract}

\section{OBJECTIVE}

We take advantage of the concurrent diffusion of unmarried cohabitation and union breakdown among French-speaking Quebeckers to examine whether family background (having grown up with unmarried parents and parental separation) and religion (reporting a denomination and religious attendance) have been key factors (intermediate variables) in the diffusion of conjugal instability or have been different consequences of a process of normative change unfolding across cohorts.

\section{METHODS}

We use a subsample of 2,265 first unions from the 2011 Canadian General Social Survey. We estimate the hazard function and the effects of the independent variables on the hazard of breakdown using Royston-Parmar flexible hazards models.

\section{RESULTS}

Results show that having grown up with unmarried parents has no effect on the hazard of breakdown despite the increasing proportion of respondents having lived in this form of family, whereas religious attendance does have an effect despite its decreasing importance. Parental separation increases the hazard of marital disruption for men but not for women.

\section{CONTRIBUTION}

Among French-speaking Quebeckers, the diffusion of unmarried cohabitation and of union breakdown seem to be two aspects of a profound shift in norms regarding family life rather than being related to each other in a direct causal way.

\footnotetext{
${ }^{1}$ Centre Urbanisation Culture Société, Institut national de la recherche scientifique, Université du Québec, Canada. E-Mail: benoit.laplante@ucs.inrs.ca.
} 


\section{Context and objectives}

The transformations that occurred in family life among French-speaking Quebeckers over the last decades, and especially the concurrent diffusion of unmarried cohabitation and union breakdown, provide a unique setting for the study of the relation between some aspects of normative and behavioural change in family life.

Union breakdown was still relatively uncommon among the people born between 1931 and 1940: Only 20\% of their first union ended in breakdown after 30 years. However, more than half of first unions broke down after fewer than 20 years among the people born between 1971 and 1980. This change did not occur alone. Whereas marriage was the normal onset of conjugal life for almost all individuals born between 1931 and 1940, more than $90 \%$ of those born between 1971 and 1980 started their conjugal life with unmarried cohabitation, most of them not having married their partner before the breakdown of the union or the time of the survey. These changes occurred as religious affiliation decreased and religious attendance plummeted. From one cohort to the next, the proportion of children who grew up with unmarried parents as well as that of children who went through the breaking up of their parents' union increased: According to vital statistics, the proportion of children born to unmarried parents increased from about 5\% in 1976 to about $60 \%$ in 2015 (ISQ 2016).

In this paper we focus on two substantive questions and one methodological problem:

- Has family background, namely not having lived with both parents until age 15 and having grown up with unmarried parents, been a key factor - an intermediate variable - in the diffusion of conjugal instability, or have such childhood events and the occurrence of union breakdown in later life been two different consequences of a process of normative change unfolding across cohorts?

- Were religious affiliation and religious attendance, which decreased across cohorts, similarly related to generational change?

- How can the hazard of breakdown of marriage and of unmarried cohabitation be analysed simultaneously in a context where unmarried cohabitation is replacing marriage as the entry into the first union and marriage becomes an optional second step for most couples?

First, we provide an overview of the circumstances of normative change in Quebec and review previous research on the intergenerational transmission of divorce and the relationship between religion and divorce. We also provide an overview of research on education and divorce and research on separation in Canada. Then we present our hypotheses, data, and methods. We conclude with results and a discussion. 


\section{Normative change in Quebec}

Until 1760, when New France became a British possession, the administration of the colony was modelled on that of a French province and, as in prerevolutionary France, the local Roman Catholic Church was largely controlled by the state. After 1760 and even more after the crushing of the 1837 rebellion against British rule, the British colonial authorities relied on the Church to develop education, health, and social services for the French-speaking Catholic majority. Things changed in the mid-1960s. In a context of rapid transformation, among which declining religious vocations was not the least important, the Church gave up its control over education, health, and social service institutions, handing them over to the Quebec government. At the same time, other organisations affiliated with the Church - of which credit unions and a large federation of trade unions were the most important - ended their religious affiliation. Meanwhile, changes in the regulation of family life that were taking place or had recently taken place in other developed Western countries were occurring in Quebec too. Civil marriage was introduced by the National Assembly in 1968. A year later the Canadian Parliament, under the initiative of a prominent Catholic intellectual, Minister of Justice P. Elliott-Trudeau, passed a statute making divorce much easier and amended the Criminal Code to end the ban on advertisements for contraception, allow abortion in certain circumstances, and decriminalise sodomy (which was widely understood as decriminalising homosexual relations). These changes occurred in the two years following the Humanae Vitae encyclical, in which the Church reaffirmed its ban on contraception, and in the wake of the Church giving up the control it had over much of the social institutions of Quebec (Laplante 2006). In this new context - in which Catholic politicians passed secularised statutes and in which being a good standing Catholic was no longer a precondition for, say, becoming a member of a credit union or getting education or health services in French French-speaking Quebeckers massively deserted weekly mass and, on family matters, quickly shifted from a traditional set of religious values and attitudes to a secularised one. Over a short period, public opinion on these matters in Quebec turned from more conservative than that of neighbouring Ontario to more progressive (Laplante, Miller, and Malherbe 2006). Marriage, whose solemnisation had remained a preserve of religious ministers until 1968, continued to be perceived a deeply religious and thus outdated institution. The rejection of divorce and remarriage by the Church added to this perception. Union libre, whose name implies the freedom of managing your conjugal relationship and ending it at will, was on its way to becoming the norm.

Statistics Canada had been doing a good job of monitoring the diffusion of unmarried cohabitation almost from the start - likely because most of its demographers were from Quebec. Consensual union - which is a far better English translation of union libre than 
'unmarried cohabitation' - had already become more common in Quebec than in the rest of Canada by 1986 (Dumas and Bélanger 1996). The diffusion process had started in the 1970s. In 1978 the Conseil du statut de la femme - the Quebec advisory board on women's status - issued an important policy document titled "Pour les Québécoises, égalité et indépendance" ("For Quebec women, equality and independence"), in which, among many things, the board recommended that the title of the Civil Code on marriage be modified so that the role of marriage as a protection instrument for dependent women living in a traditional couple be increased (CSF 1978). At the same time the board insisted that the state refrain absolutely from interfering in the economic relationships of modern equalitarian couples who had chosen to live together outside marriage. Until this point, most couples were marrying under the 'separation as to property' regime, in which there is no matrimonial property, rather than under the 'partnership of acquests' regime, in which most property acquired after the wedding is deemed jointly owned by the spouses. The reform of the rules regulating matrimonial property that followed the 1978 policy document made most property acquired after the wedding jointly owned and provided that it was to be separated equally upon divorce, no matter what property regime the spouses had chosen. From then on, marriage became, for most people, largely synonymous with the partnership of acquests regime; consensual union, then, became the functional equivalent of the old separation as to property regime. What had been a choice between two matrimonial regimes within marriage was replaced by a choice between marriage and consensual union. Although some jurists reject this analysis, many researchers agree that this new legal setting contributed to the diffusion of consensual union in Quebec (Laplante and Fostik 2015c).

That said, this modification to the Civil Code, however important, would probably not have been enough to make possible the wide diffusion of consensual union in Quebec. Two other changes were of outmost importance. The first one was the abolition of the distinction between legitimate and illegitimate children, which occurred in several steps between 1970 and the mid-1980s. The second one was the development of a legal doctrine, in Quebec as well as in the rest of Canada, which prescribes that families and couples be treated equally by third parties (the state as well as private-sector actors) whether the couple is married or not. Interestingly, this doctrine developed in Quebec as a way to sustain the difference between marriage and consensual union, whereas in the rest of Canada it was developed as part of a trend to impose the economic rules of marriage equal sharing of property upon divorce and alimony to the former spouse afterwards - to unmarried couples (Laplante and Fostik 2015c). 


\section{Previous research}

\subsection{Intergenerational transmission}

The literature generally acknowledges that there is intergenerational transmission of divorce and, over the last two decades, has been focusing on two main topics: whether or not there is a trend in the effect of parents' separation on children's marriage stability and whether the effect of parental separation is the same for men and women.

The first topic has been a focus of attention mainly in the United States, where it seems to have generated a dialogue between a limited number of researchers. McLanahan and Bumpass (1988), Teachman (2002), and $\mathrm{Li}$ and $\mathrm{Wu}$ (2008) find no trend in the intergenerational transmission of divorce, whereas Wolfinger (1999) finds that there is such a trend, the effect of parental separation on children's marriage stability having weakened by about $50 \%$ between 1973 and 1996 . He answers the methodological critique by Lin and Wu maintaining that his results were not an artifact (Wolfinger 2011).

Also in the United States Amato (1996) finds that parental divorce is associated with an increased risk of offspring divorce, especially when wives or both spouses have experienced the dissolution of their parents' marriage, some of the effect of parental divorce being mediated by age at marriage, cohabitation, socioeconomic attainment and 'prodivorce attitudes.' Still in the United States, Feng et al. (1999) find that parental divorce increased daughters' likelihood of divorce.

Diekmann and Engelhardt (1995) find that in Germany, sons of divorced parents have a much higher risk of divorce than girls have. Still in Germany, Schulz's (2009) results are more complex: For men, growing up in a postdivorce stepfamily increases the risk of future divorce, while growing up with a divorced single parent has no effect. However, for women, growing up in either postdivorce family type increases the risk of divorce. In their study of the relation between family policy and the intergenerational transmission of divorce, Engelhardt, Trappe, and Dronkers (2002) find that the strength of the intergenerational divorce transmission, adjusted for differences in the divorce level, was lower in East Germany than in West Germany. They also find a tendency towards a reduction in the strength of divorce transmission over time in both East and West Germany.

Lyngstad and Engelhardt (2009) find a complex relationship in Norway: The effect of parental divorce is stronger for women than for men, and for women there is a negative age gradient in the transmission effect. The intergenerational transmission effect is stronger for women who experienced their parents' divorce when they were young than for women who experienced it when they were old.

Two cross-national studies find the intergenerational transmission of divorce to be quite universal. Using data on women's first marriages from the Fertility and Family Surveys, Dronkers and Härkönen (2008) find that in 17 of the 18 countries they studied, 
women whose parents divorced have a significantly higher risk of divorce. Diekmann and Schmidheiny (2013) find a "substantial and highly statistically significant" transmission effect in the United States, Canada, and 13 European countries. They do not stress differences between men and women but conclude that the "intergenerational transmission of divorce is a widespread phenomenon observed without a single exception in our data covering a large number of countries with differing historical, institutional, and cultural contexts."

Another strain of research attempts to explain the transmission of divorce, but usually without reference to gender difference or change over time. Diekmann and Engelhardt (1999) stress that the gap in marital instability is between children from divorced-parent families and children from two-parent families as well as families with a widowed parent. Thus, the 'inheritance' of divorce cannot be explained by the absence of a parent alone. More or less along the same line, Wolfinger (2000) concludes that it is the strain of experiencing family structure transitions rather than the state of living without a male role model or the poverty often induced by parental divorce that explains the intergenerational transmission of divorce. Wolfinger (2003) focuses on the effects of parental family structure on spouse selection and marriage duration and finds that people from divorced families often marry other children of divorced parents, such marriages being especially likely to fail. Amato and DeBoer (2001) find that parental divorce doubled the odds that offspring would see their own marriages end in divorce; they conclude that the mechanism of the transmission of divorce involves a weak commitment to the norm of lifelong marriage rooted in parental divorce.

\subsection{Religion}

The research on the effect of religion on divorce mainly focuses on homogamy - i.e., whether spouses belonging to the same denomination or giving more or less equal importance to religious beliefs are less prone to divorce - and whether or not the risk of divorce varies across denominations.

Studies on homogamy are not numerous, likely because they require detailed data on both spouses. Although they do not limit their study to the effect of religion on divorce, Bumpass, Castro-Martín, and Sweet (1991) find that religious heterogamy reduces marital stability. Lehrer and Chiswick (1993), who focus on the effect of religion, find that with the exception of Mormons and individuals with no religious identification, stability is similar across the various types of homogamous unions, interfaith unions having generally higher rates of dissolution than intrafaith unions. Vaaler, Ellison, and Powers (2009) find that the risk of divorce is lower when husbands have conservative theological beliefs and when both partners belong to mainstream Protestant denominations. However, the risk of 
divorce is elevated when husbands attend services more frequently than their wives and when wives are more theologically conservative than their husbands.

Studies on differences between denominations are more common, especially in the United States, and their results are rather inconsistent. Sander (1993) finds that although older Baptist men are more likely to experience divorce than Catholic men and that older Catholic women are somewhat less likely to experience divorce than non-Baptist Protestant women, Catholicism has no effect on the odds that younger men and women will divorce. Using county-level aggregated data, Mullins et al. (2006) find that higher divorce rates are significantly related to a lower concentration of moderate Protestants, miscellaneous Protestants, Catholics, and Mormons. However, Glass and Levchak (2014) begin their study by asserting that states with larger proportions of religious conservatives have higher divorce rates than states with lower proportions of religious conservatives and found that moderate Protestants marry early and have low levels of educational attainment and income, which could explain a substantial portion of the association.

We did not find a true cross-national study on the relation between religion and divorce. Greenstein and Davis (2006) use data from 71 countries to study the effects of women's prestige and labour force participation on the crude divorce rate. Oddly, one of their results is that non-Roman Catholic Christian countries tend to have higher divorce rates than others.

Balakrishnan et al. (1987) is an early life-course study of divorce in Canada. The authors do not focus on religion, but they do include it among the variables they use. They find that religiosity is correlated with marriage dissolution but that denomination (i.e., being Catholic or not) does not affect the marriage dissolution probabilities once other factors are controlled.

\subsection{Education}

We do not have specific hypotheses on the relation between education and divorce, but education is used at least as a control variable in almost all studies on union instability. Härkönen and Dronkers (2006) use a cross-national approach to test whether women with higher education have a higher risk of divorce in countries where, and at times when, the social and economic costs of divorce are high, and whether there is no relationship or a negative one when and where these costs are lower. They use discrete-time event-history techniques on data on first marriages from the Fertility and Family Surveys, including direct measures on the countries' legal, social, and economic environment. They find that the deinstitutionalisation of marriage and unconventional family practices are associated with a negative educational gradient of divorce, while welfare state expenditure is associated with a more positive gradient. In Canada, Hall and Zhao (1995) find a positive 
educational gradient: Holders of postsecondary degrees face over $90 \%$ higher odds of divorce than high school graduates or those who do not graduate from high school. Their analysis focuses on the effect of premarital cohabitation and divorce.

\subsection{Research on union breakdown in Canada}

Trovato (1998; 2000) and Abada (1998) look at divorce in Canada using aggregate data focusing on interregional differences and find a regional gradient stable from one year after the 1969 reform of divorce law until the end of the 1990s. Divorce rates were lower in the Atlantic provinces and higher in the western provinces, with Ontario and Manitoba falling somewhere between the two extremes. The notable exception to the regional pattern was Quebec, where the divorce rates were similar to those of western Canada.

Wu and Balakrishnan (1995) investigate the factors that affect the breakdown of cohabitation and find gender, fertility status, partner's marital status, religion, age at start of cohabitation, year cohabitation commenced, and region were the most influential. From our perspective, the most relevant results are that the hazard of separation increases over the years and is lower in Quebec than in the rest of Canada. More interestingly, Hall and Zhao (1995) test the 'selectivity hypothesis,' according to which cohabitation is more prone to breakdown because cohabitors have some characteristics that make them different from those who choose marriage. Their results show that cohabitation is associated with a greater risk of divorce even after controlling the effects of four sociodemographic factors that differentiate cohabitors from married people. More recently, Le Bourdais, LapierreAdamcyk, and Roy (2014) have shown that cohabitation is more stable in Quebec than elsewhere in Canada, but it is still generally more unstable than marriage, although the difference in the hazard of breakdown of cohabitation and marriage tends to diminish among cohabitors who had a child and have been together for a long time. Pelletier (2015) found similar results using a different approach.

Le Bourdais and Marcil-Gratton (1998) studied the impact of family disruption in childhood on demographic outcomes in young adulthood, including the breakdown of cohabiting unions. They find family instability during childhood to be associated with the likelihood of experiencing cohabitation and a higher risk of union dissolution for married men. Martin, Mills, and Le Bourdais (2005) find similar results. Children of divorced parents have a significantly higher likelihood of entering into cohabiting unions and experiencing higher levels of divorce. Interestingly, they also find that the experience of parental divorce was shown to more steeply increase the likelihood of both marriage and cohabitation in Quebec than elsewhere in Canada.

Le Bourdais and Neill (1998) examine the factors affecting the risk of family disruption from the moment a child is born. They find that women's age at the beginning of 
the union, pre-union conceptions, and the period and conjugal setting in which the child is born all affect the odds of conjugal separation. They also find that these factors operate differently across Canada and that the gap separating cohabiting women or women who married their common-law partner from those who married directly is narrowing in Quebec.

\section{Hypotheses}

We are mainly interested in the changes in the hazard of breakdown across generations and in how such change is related to the effects of family background and religion. We are also interested in modelling such a process in a single equation for three types of unions: marriage, unmarried cohabitation, and marriage following unmarried cohabitation.

The hazard of breakdown may have increased from one generation to the next as a general tendency without any relation to the effect of family background and religion. The increase in the hazard of breakdown would thus be a general shift in norms relating to marital stability. Alternatively, the change in the hazard of breakdown across generations could be mediated through the effect of family background and religion. In such a case, the effects of the family background and religion variables would be constant across generations, but the distribution of the population across the categories of these variables would vary across generations, an increasing proportion belonging to the categories associated with a higher risk of breakdown. Finally, the association between the family background and religion variables, on the one hand, and the hazard of breakdown, on the other hand, could be spurious, the apparent effect of the former on the latter being a consequence of their common dependence on changes across generations. It goes without saying that these three basic sets of relations may be combined and that, for instance, only some of the change across generations would be mediated by family background or religion variables.

We provide more details on the operationalisation of our hypotheses in section 6 of this paper.

\section{Data and variables}

We use data from the 2011 Canadian General Social Survey. The GSS is an annual crosssectional thematic survey realised by Statistics Canada. Every five years or so since 1990, the GSS focuses on family events. The target population is all noninstitutionalised persons 15 years of age or older living in Canada's ten provinces. Data is collected directly from survey respondents. Respondents are contacted and interviewed by telephone. Households 
are selected by random digit dialling. The 2011 survey collected retrospective biographical information on a series of life events, among them the nature of the first union as well as the timing and circumstances of its formation and breakdown from a probabilistic sample of the Canadian population. In the analysis, we use a subsample of 2,265 first unions formed by French-speaking individuals born in Canada between 1931 and 1980 and residing in Quebec at the time of the survey on which we have complete information. Along with the nature, duration, and cause of the breakdown of the union, we use characteristics of the respondent (characteristics of the partner were not collected).

Unlike some American surveys, the Canadian GSS on family does not record the occurrence of parental separation during childhood but rather whether or not the respondent lived with both parents until the age of 15 . Given that death of a parent as the cause of growing up with a single parent has been a rare occurrence for a few decades, not living with both parents until age 15 is commonly held as a good proxy of parental separation among Canadian researchers, and we use it as such. Results show that, indeed, the variable behaves as such a proxy. Given that previous research consistently reports that the effect of parental separation on children's marital stability varies according to gender, we estimate the effect of this variable separately for men and women.

The detrimental effect of parental separation on children's marital stability is often interpreted to be a consequence of a negative attitude towards the ideal of a lifelong stable relationship associated with the traditional view of marriage. Such an attitude would be more prevalent among children from divorced parents than among children whose parents did not divorce. Unmarried cohabitation is similarly interpreted as a form of marital relationship that does not include the commitment to building a lifelong relationship that marriage is believed to include, and, indeed, separation is systematically higher among cohabiting couples than among married ones. Thus, having parents who lived together without being married could be associated with a lower level of marital stability. The GSS includes two questions on that topic: whether parents ever lived together in a 'common-law union' - the English Canadian name for consensual union - and whether parents were ever married to each other. We combine them to distinguish between parents who were married from the onset of cohabitation and parents who lived together before getting married. The limited number of cases does not allow distinguishing between parents who never lived together and parents who lived together but never got married. We use this new variable as a second element of family background related to the intergenerational transmission of divorce.

We use two measures of religion: denomination and attendance of religious services. Until the late 1960s, the Roman Catholic Church was an essential part of Quebec Frenchspeaking society, more or less as in Ireland or Poland. In this context, 'denomination' mainly serves to juxtapose people who still identify with the Catholic Church and those who report having no denomination. Other categories of this variable are 'Protestant' and 
'other' (which also includes the few people who did not answer the question). Religious attendance is an ordered categorical variable whose categories are 'at least once a week,' 'at least once a month,' 'a few times a year,' 'at least once a year,' and 'not at all' (which, again, also includes the few people who did not answer the question). As in all retrospective biographical surveys, the statements on religious denomination and religious attendance were collected at the time of survey. As in most studies using retrospective biographical data, we use them as proxies for religious denomination and religious attendance at the time the individuals were at risk of breaking up, with full knowledge of the limitations that go along with doing this.

Education is a five-category variable reflecting the level of education at the time of survey: 'less than secondary diploma,' 'secondary diploma,' 'some postsecondary education,' 'nonuniversity postsecondary diploma,' and 'university degree.' Nonuniversity postsecondary education is well developed and widespread in Canada and is different from university education, which justifies treating it as a separate category. To avoid reducing the number of cases without resorting to imputation, we keep missing values in a separate category.

Respondents are grouped in a ten-year birth cohort according to their year of birth. We estimate the effects of the variables we are interested in net of those of the age at the beginning of the union and of the birth of a child during the union.

\section{Method}

We estimate the hazard function and the effects of the independent variables on the hazard of breakdown using Royston-Parmar flexible proportional hazards models (Royston and Lambert 2011). This class of models can be thought of as a Cox model in which the Kaplan-Meier style baseline survival function is replaced by a restricted cubic spline function. Unlike the Kaplan-Meier estimator, which is nonparametric and implies the use of what is known as partial likelihood in the estimation of the Cox model, the cubic spline function is an algebraic representation that can be included in a likelihood function. Royston-Parmar models have several noticeable advantages. They allow a parametrised estimation of the baseline hazard function that can be easily graphed and used to compute deratives or integrals if need be. The cubic spline function adapts nicely to the increasingdecreasing hazard functions that are common in demographic research. Unlike conventional parametric models that may capture increasing-decreasing hazard functions (such as models based on the log-normal, log-logistic, or gamma distributions), they are proportional hazards models, so the effects of independent variables are easily interpreted. We provide more information on the Royston-Parmar models, their relation with the Cox model, and the way we use them in our analyses in the Appendix. 
Given the survival distributions reported in Table 1, the hazard of breakdown is likely to have increased from the oldest to the most recent generation. This could be accommodated assuming that the shape of the hazard function is the same for all generations and that the differences across generations can be modelled using a single parameter for each generation. This is a somewhat unrealistic assumption. If the dynamics of marital stability have really changed across generations, there is a good possibility that the peak of the function has moved towards the left, i.e., that the highest hazard of breakdown is experienced earlier in the life of the couple. This is best accommodated estimating a different baseline hazard function for each generation.

As reported elsewhere (e.g., Laplante 2014), most French-speaking Quebeckers from recent generations started their first union through unmarried cohabitation. Furthermore, within this population and over the last decades, unmarried cohabitation has become a mainstream context for family formation (Laplante and Fostik 2015a; 2015b). Although recent research suggests that the difference in the hazard of breakdown between marriage and unmarried cohabitation decreased over the last decades in Quebec as the proportion of cohabiting couples increased (Pelletier 2015), this difference remains substantial. Moreover, research consistently reports that the hazard of breakdown is higher among married couples who started their living together through unmarried cohabitation rather than directly through marriage. We accommodate the latter by modelling the type of union as a three-category time-varying variable: unmarried cohabitation, marriage from the onset, and marriage after unmarried cohabitation. Couples who were married from the onset remain in this category as long as they are at risk of separating. Couples who live together without being married and stay so as long as they are at risk of separating remain in their original category, but couples who initiated their conjugal life through unmarried cohabitation and married afterwards move from 'unmarried cohabitation' to 'marriage after unmarried cohabitation' at the time of their wedding.

Our analytical strategy for the identification of mediation and spurious effects is based on Aneshensel (2013). This strategy has a long history in the social sciences and can be traced back to work by Lazarsfeld and Rosenberg (1955) and further to Durkheim (1897). Assuming three variables $X$ (birth cohort), $Y$ (family background or religion variables), and $Z$ (union breakdown), interest in the effects of $X$ and $Y$ on $Z$, and a setting in which $Y$ may be 'caused' by $X$, but $X$ may not be 'caused' by $Y$, the effect of $X$ on $Z$ will be mediated through $Y$ if $Z$ varies according to $Y$ in a bivariate relationship, $Z$ varies according to $X$ in a bivariate relationship, but $Z$ varies only according to $Y$ in a three-variable model. Conversely, the effect of $Y$ on $Z$ will be spurious if both $X$ and $Y$ have an effect on $Z$ in bivariate relationships but only $X$ has an effect in a three-variable relationship. 
Table 1: Proportion of unions surviving at selected anniversaries by cohort. First unions formed by French-speaking individuals born in Canada between 1931 and 1980, and residing in Quebec at the time of survey

\begin{tabular}{rccccc}
\hline & $\mathbf{1 9 3 1}$ & $\mathbf{1 9 4 1}$ & $\mathbf{1 9 5 1}$ & $\mathbf{1 9 6 1}$ & $\mathbf{1 9 7 1}$ \\
\hline 1 & 0.9951 & 0.9783 & 0.9594 & 0.9454 & 0.9138 \\
2 & 0.9859 & 0.9596 & 0.9341 & 0.8861 & 0.8227 \\
3 & 0.9837 & 0.9479 & 0.9029 & 0.8399 & 0.7717 \\
4 & 0.9819 & 0.9344 & 0.8793 & 0.7925 & 0.7326 \\
5 & 0.9776 & 0.9195 & 0.8497 & 0.7549 & 0.6985 \\
10 & 0.9643 & 0.8467 & 0.7573 & 0.6359 & 0.5737 \\
15 & 0.9338 & 0.7950 & 0.6866 & 0.5619 & 0.5117 \\
20 & 0.8803 & 0.7346 & 0.6297 & 0.5247 & 0.4620 \\
25 & 0.8243 & 0.7009 & 0.5843 & 0.4897 & - \\
30 & 0.7994 & 0.6773 & 0.5697 & 0.4719 & - \\
\hline
\end{tabular}

Source: Statistics Canada, General Social Survey 2011. Kaplan-Meier estimator of the survivor function. Weighted estimation.

\section{Results}

Table 1 shows that the proportion of surviving unions decreased in quite a regular fashion from the oldest cohort to the youngest. This is true for the first few years after the onset of the union as well as after 20 years. It is still true after 30 years among the cohorts whose unions may be observed up to that point. Figure 1 reports the evolution of the hazard of union breakdown as a function of time elapsed since the onset of the union by birth cohort. The main feature is the emergence of a strong dependence of the hazard on time. In the 1931 and 1941 cohort, the hazard is low and does not vary much over time: the risk of union breakdown appears as almost constant. From the 1951 to the 1971 cohort, the hazard of breakdown becomes time-dependent, with the highest values concentrated in the first few years of the union and the peak of the function increasing from one cohort to the next.

Table 2 shows changes across cohorts in the distribution of some characteristics usually related to the hazard of union breakdown. In this table, we include information about the 1981 cohort, which is not included in the analysis, to make trends more obvious. The proportion of couples who began their union through marriage drops from $98.2 \%$ in the oldest cohort to $7.5 \%$ in the 1971 cohort and $4.8 \%$ in the 1981 one. The proportion of couples who started their union through unmarried cohabitation and married afterwards increases and reaches its peak within the 1961 cohort, then decreases. The proportion of couples who started their union through unmarried cohabitation and had not married increases and reaches $75.3 \%$ in the 1971 cohort and $88.3 \%$ in the 1981 cohort. Some of the unions formed by couples from the most recent cohort may turn into marriage after the 
time of survey, but the trend is still very strong. The proportion of respondents who hold a university degree or nonuniversity postsecondary diploma increases from the oldest to the most recent cohort, while the proportion of respondents who have some postsecondary education without a degree or diploma increases, then decreases, and the proportion of people holding only secondary education decreases.

Figure 1: Hazard of breakdown by birth cohort. First unions formed by French-speaking individuals born in Canada between 1931 and 1980 and residing in Quebec at the time of survey. Proportional hazards model with cubic spline hazard function. Gross effects

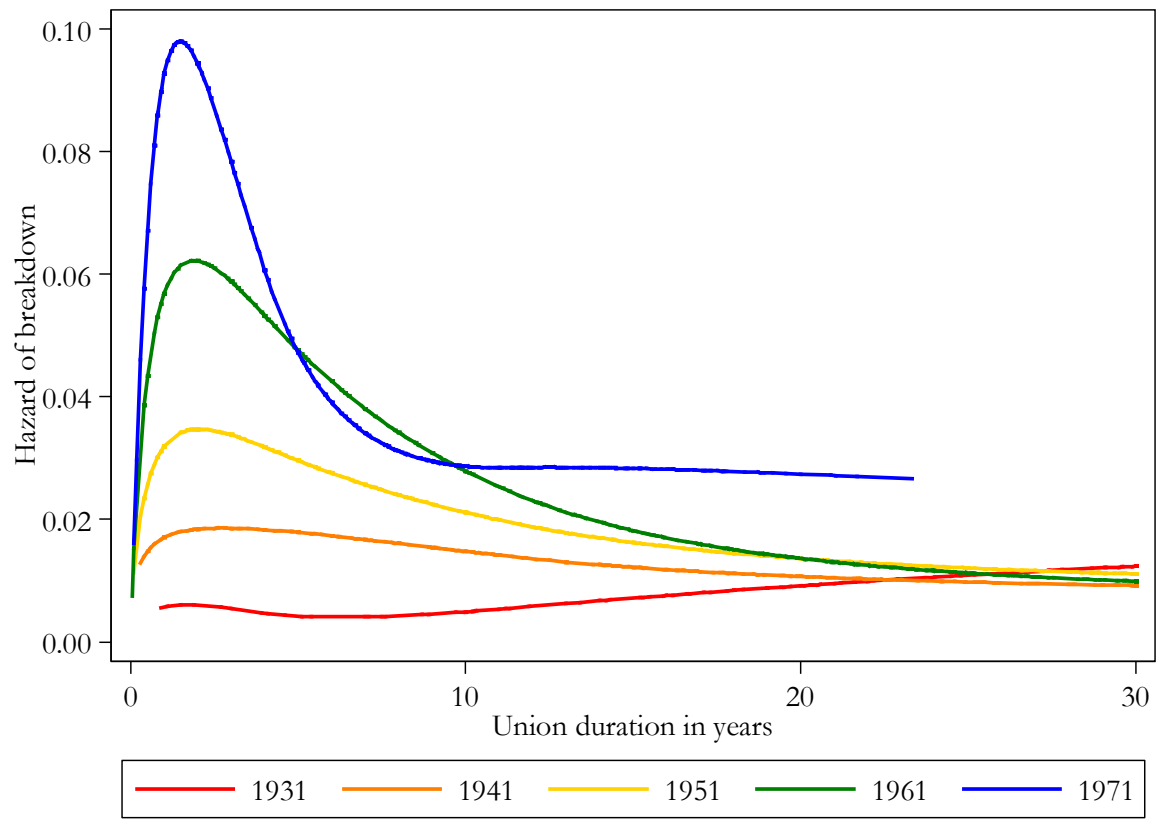


Table 2: $\quad$ Selected characteristics by birth cohort. First unions formed by French-speaking individuals born in Canada between 1931 and 1980, and residing in Quebec at the time of survey. Individual characteristics from the respondent. Proportion of cases except when specified otherwise

\begin{tabular}{|c|c|c|c|c|c|c|}
\hline & 1931 & 1941 & 1951 & 1961 & 1971 & 1981 \\
\hline \multicolumn{7}{|l|}{ Type of union } \\
\hline Marriage & 0.982 & 0.865 & 0.524 & 0.217 & 0.075 & 0.048 \\
\hline Marriage after cohabitation & 0.008 & 0.070 & 0.236 & 0.328 & 0.172 & 0.069 \\
\hline Unmarried cohabitation & 0.011 & 0.065 & 0.240 & 0.455 & 0.753 & 0.883 \\
\hline Age at beginning of the union ${ }^{1}$ & 24.3 & 23.8 & 23.7 & 23.8 & 23.3 & 21.7 \\
\hline Presence of a child ${ }^{2}$ & 0.797 & 0.740 & 0.682 & 0.654 & 0.490 & \\
\hline \multicolumn{7}{|l|}{ Sex } \\
\hline Man & 0.456 & 0.474 & 0.484 & 0.492 & 0.475 & 0.489 \\
\hline Woman & 0.544 & 0.526 & 0.516 & 0.508 & 0.525 & 0.511 \\
\hline \multicolumn{7}{|l|}{ Education } \\
\hline University degree & 0.140 & 0.175 & 0.217 & 0.229 & 0.289 & 0.304 \\
\hline Nonuniversity PS diploma & 0.128 & 0.233 & 0.283 & 0.355 & 0.450 & 0.445 \\
\hline Some postsecondary education & 0.046 & 0.101 & 0.124 & 0.119 & 0.110 & 0.075 \\
\hline Secondary diploma & 0.145 & 0.126 & 0.183 & 0.147 & 0.062 & 0.076 \\
\hline Less than secondary diploma & 0.531 & 0.364 & 0.192 & 0.148 & 0.089 & 0.100 \\
\hline Unknown & 0.010 & 0.001 & 0.002 & 0.003 & 0.000 & 0.000 \\
\hline \multicolumn{7}{|c|}{ Parents ever lived together without being married } \\
\hline Yes & 0.010 & 0.011 & 0.016 & 0.041 & 0.294 & 0.572 \\
\hline No & 0.990 & 0.989 & 0.984 & 0.959 & 0.706 & 0.428 \\
\hline \multicolumn{7}{|l|}{ Parents got married to each other } \\
\hline Yes & 1.000 & 0.995 & 0.995 & 0.979 & 0.971 & 0.852 \\
\hline No & 0.000 & 0.005 & 0.005 & 0.021 & 0.029 & 0.148 \\
\hline \multicolumn{7}{|c|}{ Lived with both parents until age 15} \\
\hline Yes & 0.886 & 0.903 & 0.894 & 0.830 & 0.754 & 0.745 \\
\hline No & 0.114 & 0.097 & 0.106 & 0.170 & 0.246 & 0.255 \\
\hline \multicolumn{7}{|l|}{ Denomination } \\
\hline No denomination & 0.022 & 0.054 & 0.073 & 0.072 & 0.173 & 0.173 \\
\hline Roman Catholic & 0.963 & 0.927 & 0.899 & 0.897 & 0.776 & 0.770 \\
\hline Protestant & 0.013 & 0.015 & 0.019 & 0.028 & 0.032 & 0.051 \\
\hline Other & 0.002 & 0.004 & 0.008 & 0.003 & 0.018 & 0.006 \\
\hline
\end{tabular}


Laplante: Family background, religion, and generational change in the diffusion of first union breakdown

Table 2: (Continued)

\begin{tabular}{lcccccc}
\hline & $\mathbf{1 9 3 1}$ & $\mathbf{1 9 4 1}$ & $\mathbf{1 9 5 1}$ & $\mathbf{1 9 6 1}$ & $\mathbf{1 9 7 1}$ & $\mathbf{1 9 8 1}$ \\
\hline Religious attendance & & & & & & \\
At least once a week & 0.315 & 0.149 & 0.053 & 0.032 & 0.007 & 0.013 \\
At least once a month & 0.105 & 0.100 & 0.051 & 0.041 & 0.035 & 0.008 \\
A few times a year & 0.144 & 0.256 & 0.234 & 0.248 & 0.155 & 0.157 \\
At least once a year & 0.123 & 0.116 & 0.147 & 0.213 & 0.205 & 0.200 \\
Not at all & 0.314 & 0.379 & 0.515 & 0.465 & 0.598 & 0.622 \\
Unknown & 0.315 & 0.149 & 0.053 & 0.032 & 0.007 & 0.013 \\
$\boldsymbol{N}$ & 275 & 520 & 622 & 422 & 425 & 233 \\
\hline
\end{tabular}

Source: Statistics Canada, General Social Survey 2011. Weighted estimation. Estimates based on the data from the public use microdata file, except when specified otherwise.

${ }^{1}$ Estimates based on confidential data. Mean rather than proportion.

${ }^{2}$ Estimates based on confidential data. Proportion of time at risk rather than proportion of the cases.

The proportion of respondents who declare themselves to be Roman Catholic decreases across cohorts, whereas the proportion of respondents who declare having no denomination increases. Attendance of religious services decreases in the same fashion. The proportion of respondents whose parents ever lived together without being married is very low in the oldest cohorts, but $4.1 \%$ in the 1961 cohort, $29.4 \%$ in the 1971 cohort, and $57.2 \%$ in the most recent cohort. The proportion of respondents whose parents never got married is very low except in the 1981 cohort, which we do not use in our analyses. This is a limitation of this variable for our purposes. The proportion of respondents who lived with both their parents until age 15 increases from the 1931 to the 1941 cohort then decreases, which suggests that this variable may capture death of a parent more than parental separation among the older cohorts, which would be a limitation of its use for our purposes. The diffusion of separation and that of unmarried cohabitation are both closely associated with the year of birth.

Table 3 reports the estimates of the effects of the characteristics we are interested in on the hazard of breakdown. Column 1a reports the estimates of the gross effects of the independent variables from a series of equations using each a single independent variable. Column $1 \mathrm{~b}$ reports results from a similar series of equations in which the effect of each of these independent variable is estimated net of the effect of birth cohort. As we explain in the Appendix, we parametrise the effect of birth cohort as a series of strata using cubic spline functions.

Education has little effect on breakdown: Having some postsecondary education increases the hazard of breakdown. Not having lived with both parents until age 15 increases the hazard of breakdown for men, and this effect remains significant when controlling cohort. There is no such effect for women. Having parents who were never 
married to each other increases the hazard too, and this effect increases when controlling parents' separation; however, this effect disappears when controlling cohort.

Column 2a reports the effects of the two measures of family background net of each other. Column 2b reports the effects of these two measures controlling birth cohort. All effects remain unaffected by these controls, except having had parents who lived together without being married.

Roman Catholics and Protestants are as likely to stop living together, both less than people who have no denomination or have another one; these differences remain when controlling birth cohort. Religious attendance reduces the hazard of breakdown, even when controlling birth cohort. The effects of the two measures of religiosity remain substantially similar when estimated in the same equation (column 2a) and when controlling birth cohort (columns $1 \mathrm{~b}$ and $2 \mathrm{~b}$ ).

Table 3: $\quad$ Effects of selected characteristics on the hazard of breakdown. First unions formed by French-speaking individuals born in Canada between 1931 and 1980 and residing in Quebec at the time of survey. Individual characteristics from the respondent. Proportional hazards model with cubic spline hazard function

\begin{tabular}{|c|c|c|c|c|c|c|c|}
\hline & 1a & 1b & $2 a$ & $2 b$ & 3 & 4 & 5 \\
\hline \multicolumn{8}{|l|}{ Type of union ${ }^{1}$ [Marriage from onset] } \\
\hline Marriage after cohabitation & $2.118^{*+t}$ & $2.018^{+*+t}$ & & & & $1.990^{+* * t}$ & $2.340^{\text {t*t* }}$ \\
\hline (Marriage after cohabitation) $\cdot t$ & & & & & & & 0.975 \\
\hline Unmarried cohabitation & $5.698^{+4+x}$ & $5.384^{+* t+}$ & & & & $5.091^{+* t+}$ & $14.412^{\text {t+t+ }}$ \\
\hline (Unmarried cohabitation) $\cdot t$ & & & & & & & $0.861^{*+*}$ \\
\hline Age at beginning of the union & $0.959^{\text {tat }}$ & $0.965^{\text {t*t }}$ & & & $0.964^{*+t}$ & $0.948^{*+*}$ & $0.950^{*+*}$ \\
\hline Presence of a child ${ }^{1}$ & $0.432^{\text {t*t+ }}$ & $0.480^{+* * t}$ & & & $0.480^{*+1+}$ & $0.595^{*+*}$ & $0.584^{\text {t*t }}$ \\
\hline \multicolumn{8}{|c|}{ Education [Less than secondary diploma] } \\
\hline University degree & 1.188 & 1.048 & & & 1.077 & 1.074 & 1.086 \\
\hline Nonuniversity PS diploma & $1.283^{*}$ & 1.076 & & & 1.101 & 1.109 & 1.118 \\
\hline Some postsecondary education & $1.666^{n+*}$ & $1.489^{*+}$ & & & $1.443^{*}$ & $1.474^{*+}$ & $1.417^{*}$ \\
\hline Secondary diploma & 0.894 & 1.100 & & & 1.122 & 1.015 & 1.029 \\
\hline Unknown & 0.971 & 1.383 & & & 1.116 & 0.881 & 1.176 \\
\hline \multicolumn{8}{|l|}{ FAMILY BACKGROUND } \\
\hline \multicolumn{8}{|c|}{ Parents' type of union [Married from the onset] } \\
\hline Cohabitation then marriage & $2.190^{n+* t+}$ & $1.390^{*}$ & $2.052^{n+* x}$ & 1.330 & 1.313 & 1.147 & 1.147 \\
\hline Other & $1.995^{* *}$ & 1.405 & 1.765 & 1.290 & 1.353 & 1.350 & 1.340 \\
\hline
\end{tabular}


Laplante: Family background, religion, and generational change in the diffusion of first union breakdown

Table 3: (Continued)

\begin{tabular}{|c|c|c|c|c|c|c|c|}
\hline & $1 \mathbf{a}$ & 1b & $2 a$ & 2b & 3 & 4 & 5 \\
\hline \multicolumn{8}{|c|}{ Lived with both parents until age $\mathbf{1 5}$ by gender [Yes for men] } \\
\hline No for men & $1.962^{* \star \star *}$ & $1.693^{\star \star \star}$ & $1.686^{\star \star \star}$ & $1.610^{* * *}$ & $1.589^{\star \star \star}$ & $1.437^{\star}$ & $1.426^{*}$ \\
\hline Yes for women & 1.082 & 1.097 & 1.097 & 1.102 & 1.100 & 1.163 & 1.165 \\
\hline No for women & 1.126 & 1.001 & 1.031 & 0.972 & 0.912 & 0.954 & 0.942 \\
\hline \multicolumn{8}{|l|}{ RELIGION } \\
\hline \multicolumn{8}{|c|}{ Denomination [Roman Catholic] } \\
\hline No denomination & $2.259^{* * *}$ & $1.839^{* \star \star}$ & $1.841^{\star \star \star}$ & $1.605^{\star \star *}$ & $1.600^{* * \star}$ & $1.567^{* \star *}$ & $1.535^{* * *}$ \\
\hline Protestant & 0.939 & 0.818 & 1.212 & 0.987 & 0.913 & 0.862 & 0.861 \\
\hline Other & $4.252^{\star \star *}$ & $3.546^{\star \star \star}$ & $3.521^{\star *}$ & $3.141^{\star *}$ & $2.899^{* *}$ & 2.171 & $2.500^{*}$ \\
\hline \multicolumn{8}{|c|}{ Religious attendance [At least once a week] } \\
\hline At least once a month & $2.088^{* *}$ & $1.707^{*}$ & $2.113^{* *}$ & $1.716^{*}$ & 1.684 & 1.592 & 1.601 \\
\hline A few times a year & $2.306^{\star \star *}$ & $1.591^{*}$ & $2.333^{\star \star *}$ & $1.599^{*}$ & 1.499 & 1.481 & 1.518 \\
\hline At least once a year & $3.514^{* \star *}$ & $2.234^{* \star \star}$ & $3.478^{* \star *}$ & $2.206^{* \star *}$ & $2.097^{\star \star}$ & $1.986^{* *}$ & $1.985^{* *}$ \\
\hline Not at all & $3.981^{* * *}$ & $2.615^{\star * \star}$ & $3.626^{* \star *}$ & $2.422^{*+*}$ & $2.118^{*+* t}$ & $1.789^{* *}$ & $1.844^{* *}$ \\
\hline
\end{tabular}

\section{Meaning of column titles}

1a: Gross effects: one equation for each independent variable.

1b: Same as 1a, but controlling birth cohort.

2a: Results from two different equations: one in which both family background variables are used as independent variables, the other in which both religion variables are used as independent variables.

2b: Same as 2a but controlling birth cohort.

3: A single equation including all independent variables except the type of union and controlling birth cohort.

4: Same as 3 but including type of union as a time-varying variable.

5: Same as 4, but including type of union as a time-varying variable with a time-varying effect.

Source: Statistics Canada, General Social Survey 2011. Weighted estimation. Reference category within brackets.

${ }^{1}$ Time-varying variable.

${ }^{*} p<0.05 ;{ }^{* *} p<0.01 ;{ }^{* * *} p<0.001$

The effect of the type of union net of that of birth cohort (column 1b) is similar to its gross effect (column 1a).

Column 3 reports the estimates from a single equation that includes all independent variables but type of union - which we introduce later - while controlling birth cohort. These mutual controls do not induce further change. Column 4 reports the estimates from a single equation similar to that of column 3 but controlling, furthermore, the effect of the type of union parametrised as a time-varying variable with constant effects. This additional control does not induce further change either. 
Assuming that the effect of the type of union is constant could be too simplistic. Living as an unmarried couple increases the hazard of breakdown, which is expected, but assuming that this difference is constant for the whole duration of unions could be unrealistic. As couples who are more prone to separate do so, the remaining couples could be less prone to separate and the difference between cohabiting unions and marriage could decrease as people have lived together longer. In all our equations, type of union is a timevarying variable. Column 5 reports the estimate of an equation similar to that of column 4 but in which the effects of the categories of type of union are specified as a function of time. We comment these results below when discussing Figure 3.

According to these results, 'just living together' rather than being married from the onset increases sharply the hazard of breakdown at the beginning of the union, but the difference decreases over time. Being married after having started to live together rather than being married from the onset also increases the hazard of breakdown, but not as much as not being married, and the difference could decrease somewhat over time - despite the slope of the effect being apparently nonsignificant. Accommodating the time-varying nature of the difference between the effects of the various types of union does not alter significantly the effects of the other characteristics.

Figure 2 reports the hazard of breakdown of marriage by birth cohort as estimated in the equation reported in column 5 of Table 3 . The peaks of the hazard functions are lower than the peaks of the corresponding functions in Figure 1, suggesting that the functions for unmarried cohabitation are even higher. The shape of the function of the 1931 cohort similar to the shape of the corresponding function in Figure 1 but more striking here because of its scale and because of the level of the functions of the other cohorts - suggests that the hazard of separation truly increased with time among this cohort. This is easily explained as a period effect: In Canada and even more so in Quebec, the law made divorce extremely difficult until 1969. Consequently, for people born between 1931 and 1940, divorce became available long after they had married, and the hazard of separation increases as a function of the duration of the marriage. 
Figure 2: Hazard of breakdown of marriage by birth cohort. First unions formed by French-speaking individuals born in Canada between 1931 and 1980 and residing in Quebec at the time of survey. Proportional hazards model with cubic spline hazard function. Net effects from column 5 (Table 3)

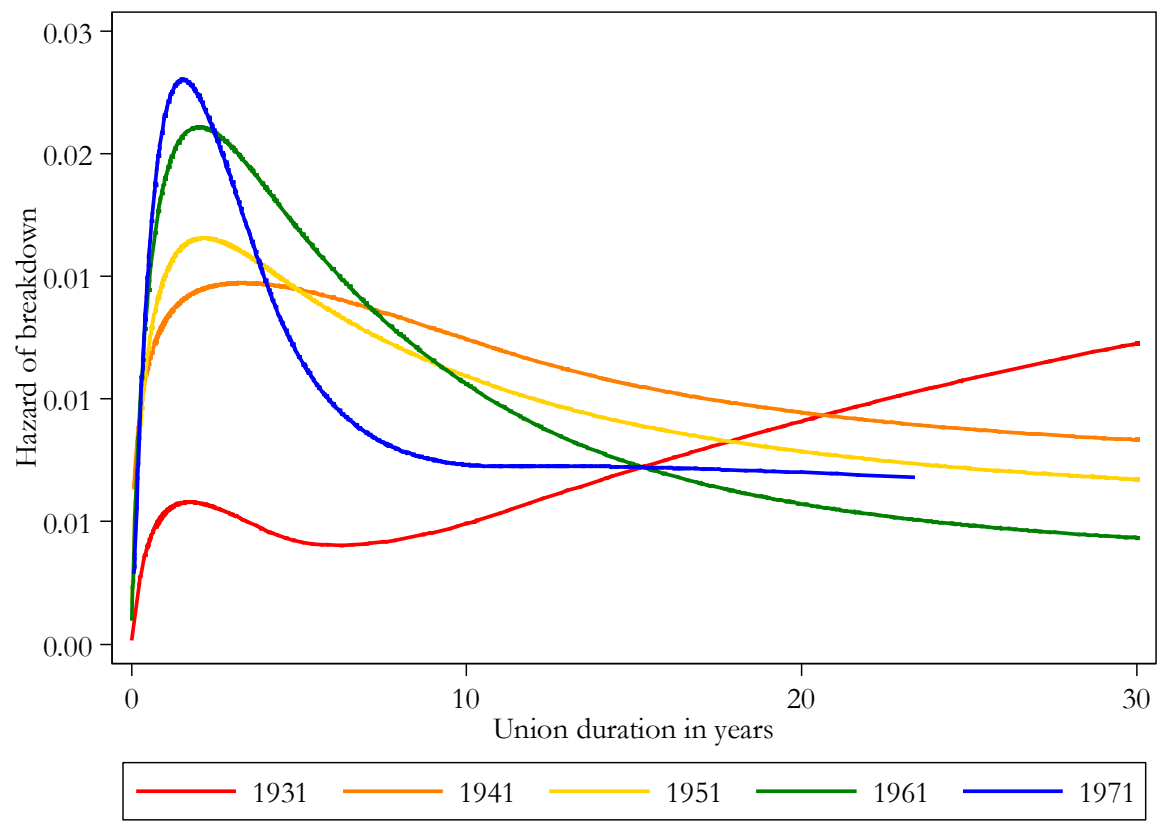


Figure 3: Hazard of breakdown by type of union. First unions formed by French-speaking individuals born in Canada between 1931 and 1980 and residing in Quebec at the time of survey. Time-varying specification. Proportional hazards model with cubic spline hazard function. Net effects from column 5 (Table 3)

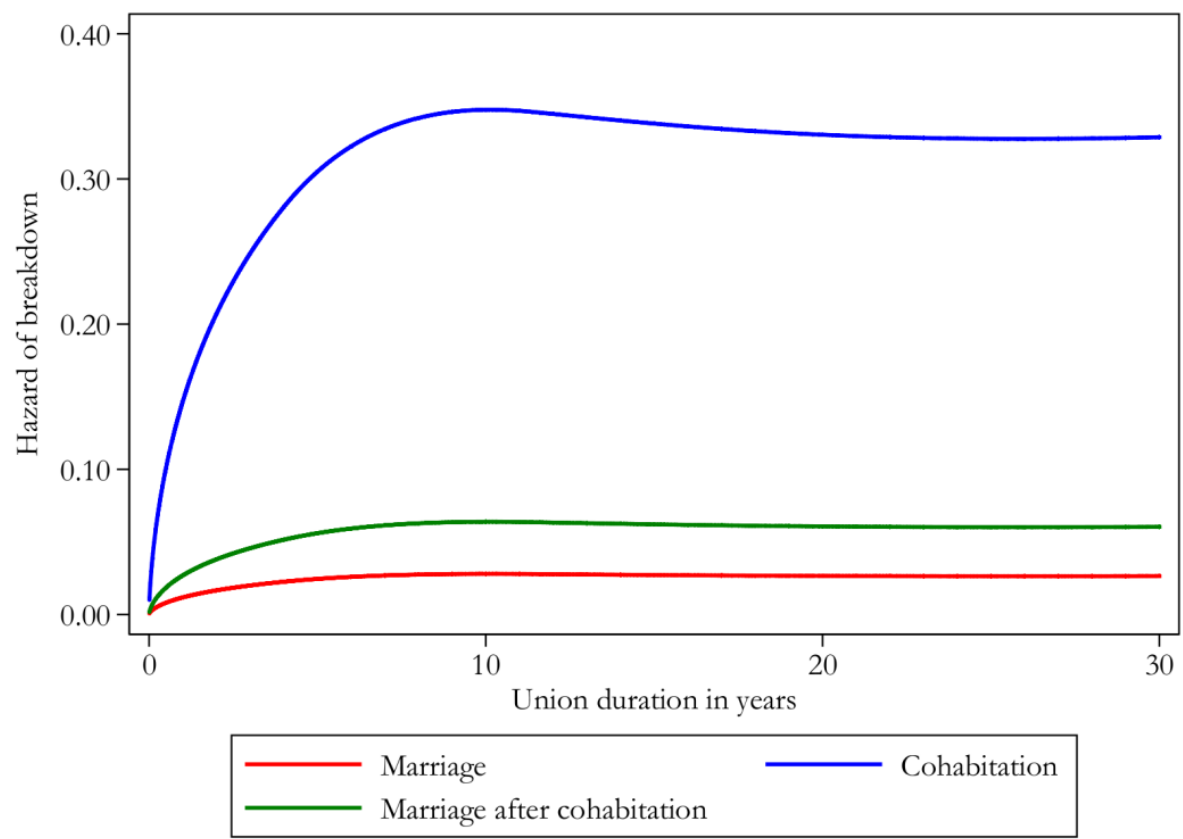

Figure 3 reports the baseline effect of the three types of union specified as a timevarying variable having a time-varying effect as estimated in the equation reported in column 5 of Table 3. The hazard of breakdown for marriage following unmarried cohabitation is about twice the hazard for marriage, but this difference is dwarfed by the difference between the hazard of breakdown for unmarried cohabitation and those of marriage and marriage following the beginning of cohabitation. In this figure, we depict the hazard functions for the 1951 cohort. The distance between the function for unmarried cohabitation and the function for marriage decreases as time increases, as can be expected given the coefficients of the time-varying effect. Interestingly, for the 1931 cohort the difference between these two hazard functions - not depicted here - increases over time despite the value of the slope of the time-varying effect. This is likely a consequence of the 
1969 divorce reform, whose effect - a period effect - is 'glued' with the baseline hazard of the 1931 cohort, for which it cancels and reverses the decrease of the difference between the hazard of marriage and unmarried cohabitation.

\section{Discussion}

The effect of having lived with unmarried parents behaves as a spurious correlation: It disappears when controlling birth cohort. The proportion of children whose parents have never been married increases from the older birth cohorts to the younger, as does the hazard of breakdown, but having lived with unmarried parents has no effect on children's marital stability.

Not having lived with both parents until age 15 decreases marital stability for men. This effect is constant and robust. Having parents who lived together without being married has a gross effect, and this effect increases when controlling parents' separation. Taken literally and without further control, this would suggest that unmarried parents are somewhat less likely to separate but that having unmarried parents makes male offspring more prone to separate, which is very unlikely. Actually, having had parents who lived together without being married loses its effect on separation when controlling cohort. This suggests that the apparent causal structure involving parents' separation and parents' unmarried cohabitation is spurious, as both become more common across cohorts. Having had parents who lived together without being married does not increase the hazard of separation among offspring, but parents' unmarried cohabitation and parents' separation both increase across cohorts.

Religious affiliation and practice, although they both decrease from the oldest to the youngest birth cohorts, do have a straightforward and constant effect on the hazard of breakdown.

There is no obvious explanation for the effect of education and especially not for the very robust effect of having some postsecondary education. Perhaps having some postsecondary education without having the expected diploma or degree is associated with some personal characteristic related to the hazard of breakdown, or such incomplete training leads individuals to some ill-defined and, hence, precarious position on the marriage or labour market that increases the hazard of breakdown.

\section{Conclusion}

The effect of having lived with unmarried parents on union breakdown is spurious. As unmarried cohabitation has become more common from the oldest to the youngest cohort, 
more children have experienced this environment in their childhood, and, as unmarried cohabitation becomes more common across cohorts, they live themselves in cohabiting relationships and are more prone to break their conjugal unions because of the dynamics of unmarried cohabitation and not because their parents were themselves unmarried. According to our results, this is not intergenerational transmission but diffusion.

The effect of parental separation on children's marital stability is not spurious, although it is limited to men. Whether they are married or not, men who experienced parental separation in their childhood tend to experience the breakdown of their own union more often than men who did not experience that event.

The effects of religious affiliation and of religious attendance are not correlated with the change, across cohorts, in the proportion of individuals having a religious affiliation and attending religious services. The diminishing proportions of people having a religious affiliation and attending religious services may be viewed as cultural changes and thus as parts of the broad normative shift the Quebec French-speaking society underwent and of which the diffusion of unmarried cohabitation and of union breakdown are also a part. However, unlike that of parental unmarried cohabitation, the effects of religious affiliation and of religious attendance on union breakdown are not spurious. In other words, as seen in section 2, the Quebec French-speaking society seems to have undergone a massive normative shift of which the diffusion of unmarried cohabitation and union instability are two important but distinct components.

Finally, according to our results, both birth cohort and type of union have nonproportional effects on the hazard of breakdown. This is not commonly acknowledged in studies on union breakdown, and researchers should be reminded to use modelling strategies that accommodate the nonproportional effects of both variables.

\section{Acknowledgments}

This research was supported by the Social Sciences and Humanities Research Council of Canada.

The analysis presented in this article was conducted at the Quebec Interuniversity Centre for Social Statistics, which is part of the Canadian Research Data Centre Network (CRDCN). The services and activities provided by the QICSS are made possible by the financial or in-kind support of the Social Sciences and Humanities Research Council (SSHRC), the Canadian Institutes of Health Research (CIHR), the Canada Foundation for Innovation (CFI), Statistics Canada, the Fonds de recherche du Québec-Société et culture (FRQSC), and the Quebec universities. The views expressed in this paper are those of the authors and not necessarily those of the CRDCN or its partners. 


\section{References}

Abada, T. (1998). Provincial differences in divorce in Canada: An analysis of period, province and duration. In: Contributions to family demography: Essays in honour of Dr. Wayne W. McVey, Jr. Edmonton: Department of Sociology, University of Alberta: 1-24.

Amato, P.R. (1996). Explaining the intergenerational transmission of divorce. Journal of Marriage and Family 58(3): 628-640. doi:10.2307/353723.

Amato, P.R. and DeBoer, D.D. (2001). The transmission of marital instability across generations: Relationship skills or commitment to marriage? Journal of Marriage and Family 63(4): 1038-1051. doi:10.1111/j.1741-3737.2001.01038.x.

Aneshensel, C.S. (2013). Theory-based data analysis for the social sciences. Thousand Oaks: Sage. doi:10.4135/9781506335094.

Balakrishnan, T.R., Rao, K.V., Lapierre-Adamcyk, É., and Krotki, K.J. (1987). A hazard model analysis of the covariates of marriage dissolution in Canada. Demography 24(3): 395-406. doi:10.2307/2061305.

Bumpass, L.L., Castro-Martín, T., and Sweet, J.A. (1991). The impact of family background and early marital factors on marital disruption. Journal of Family Issues 12(1): 22-42. doi:10.1177/019251391012001003.

Conseil du statut de la femme (CSF). (1978). Pour les Québécoises: Égalité et indépendance. Quebec City: Éditeur officiel du Québec.

Cox, D.R. (1972). Regression models and life-tables. Journal of the Royal Statistical Society. Series B (Methodological) 34(2): 187-220.

Diekmann, A. and Engelhardt, H. (1995). Sex-specific effects in the intergenerational transmission of divorce risks. Zeitschrift für Soziologie 24(3): 215-228.

Diekmann, A. and Engelhardt, H. (1999). The social inheritance of divorce: Effects of parent's family type in postwar Germany. American Sociological Review 64(6): 783-793. doi:10.2307/2657402.

Diekmann, A. and Schmidheiny, K. (2013). The intergenerational transmission of divorce: A fifteen-country study with the Fertility and Family Survey. Comparative Sociology 12(2): 211-235. doi:10.1163/15691330-12341261.

Dronkers, J. and Härkönen, J. (2008). The intergenerational transmission of divorce in cross-national perspective: Results from the Fertility and Family Surveys. Population Studies 62(3): 273-288. doi:10.1080/00324720802320475. 
Dumas, J. and Bélanger, A. (1996). Common-law unions in Canada at the end of the $20^{\text {th }}$ Century. In: Dumas, J. (ed.) Report on the demographic situation in Canada. Ottawa: Statistics Canada: 123-181.

Durkheim, É. (1897). Le suicide: Étude de sociologie. Paris: F. Alcan.

Engelhardt, H., Trappe, H., and Dronkers, J. (2002). Differences in family policy and the intergenerational transmission of divorce: A comparison between the former East and West Germany. Demographic Research 6(11): 295-324. doi:10.4054/DemRes. 2002.6.11.

Feng, D., Giarrusso, R., Bengtson, V.L., and Frye, N. (1999). Intergenerational transmission of marital quality and marital instability. Journal of Marriage and Family 61(2): 451-463. doi:10.2307/353761.

Glass, J. and Levchak, P. (2014). Red states, blue states, and divorce: Understanding the impact of conservative Protestantism on regional variation in divorce rates. American Journal of Sociology 119(4): 1002-1046. doi:10.1086/674703.

Greenstein, T.N. and Davis, S.N. (2006). Cross-national variations in divorce: Effects of women's power, prestige and dependence. Journal of Comparative Family Studies 37(2): 253-273.

Hall, D.R. and Zhao, J.Z. (1995). Cohabitation and divorce in Canada: Testing the selectivity hypothesis. Journal of Marriage and Family 57(2): 421-427. doi:10.2307/353695.

Härkönen, J. and Dronkers, J. (2006). Stability and change in the educational gradient of divorce: A comparison of seventeen countries. European Sociological Review 22(5): 501-517. doi:10.1093/esr/jcl011.

ISQ [Institut de la statistique du Québec] (2016). Naissances selon l'état matrimonial des parents, Québec, 1951-2015. http://stat.gouv.qc.ca/statistiques/populationdemographie/naissance-fecondite/410.htm. [Retrieved on 24 ${ }^{\text {th }}$ July 2016.]

Kaplan, E.L. and Meier, P. (1958). Nonparametric estimation from incomplete observations. Journal of the American Statistical Association 53(282): 457-481. doi:10.1080/01621459.1958.10501452.

Laplante, B. (2006). The rise of cohabitation in Quebec: Power of religion and power over religion. Canadian Journal of Sociology 31(1): 1-24. doi:10.2307/20058678.

Laplante, B. (2014). Normative groups: The rise of the formation of the first union through cohabitation in Quebec, a comparative approach. Population Research and Policy Review 33(2): 257-285. doi:10.1007/s11113-013-9279-4. 
Laplante, B. and Fostik, A.L. (2015a). Disentangling the Quebec fertility paradox: The recent evolution of fertility within marriage and consensual union in Quebec and Ontario. Canadian Studies in Population 42(1-2): 81-101.

Laplante, B. and Fostik, A.L. (2015b). Two period measures for comparing the fertility of marriage and cohabitation. Demographic Research 32(14): 421-442. doi:10.4054/ DemRes.2015.32.14.

Laplante, B. and Fostik, A.L. (2015c). L'égalité, l'indépendance et l'union de fait: Le choix de l'union de fait et du mariage au Québec et en Ontario de 1986 à 2011. Montreal: Centre UCS de l'INRS. (Inédit/Working paper, n²015-06).

Laplante, B., Miller, C., and Malherbe, P. (2006). The evolution of beliefs and opinions on matters related to marriage and sexual behaviour of French-speaking Catholic Quebecers and English-speaking Protestant Ontarians. Canadian Studies in Population 33(2): 205-235.

Lazarsfeld, P.F. and Rosenberg, M. (1955). The language of social research: A reader in the methodology of social research. Glencoe: Free Press.

Le Bourdais, C., Lapierre-Adamcyk, É., and Roy, A. (2014). Instabilité des unions libres: Une analyse comparative des facteurs démographiques. Recherches sociographiques 55(1): 53-78. doi:10.7202/1025645ar.

Le Bourdais, C. and Marcil-Gratton, N. (1998). The impact of family disruption in childhood on demographic outcomes in young adulthood. In: Corak, M. (ed.). Labour markets, social institutions, and the future of Canada's children. Ottawa: Statistics Canada: 91-105.

Le Bourdais, C. and Neill, G. (1998). Are mom and dad married? And does it matter for the future of the family? In: Contributions to family demography: Essays in honour of Dr. Wayne W. McVey. Edmonton: Department of Sociology, University of Alberta: 75-97.

Lehrer, E.L. and Chiswick, C.U. (1993). Religion as a determinant of marital stability. Demography 30(3): 385-404. doi:10.2307/2061647.

Li, J.C.A. and Wu, L.L. (2008). No trend in the intergenerational transmission of divorce. Demography 45(4): 875-883. doi:10.1353/dem.0.0030.

Lyngstad, T.H. and Engelhardt, H. (2009). The influence of offspring's sex and age at parents' divorce on the intergenerational transmission of divorce, Norwegian first marriages 1980-2003. Population Studies 63(2): 173-185. doi:10.1080/0032 4720902896044. 
Martin, V., Mills, M., and Le Bourdais, C. (2005). The consequences of parental divorce on the life course. Canadian Studies in Population 32(1): 29-51.

McLanahan, S. and Bumpass, L.L. (1988). Intergenerational consequences of family disruption. American Journal of Sociology 94(1): 130-152. doi:10.1086/228954.

Mullins, L.C., Brackett, K.P., Bogie, D.W., and Pruett, D. (2006). The impact of concentrations of religious denominational affiliations on the rate of currently divorced in counties in the United States. Journal of Family Issues 27(7): 9761000. doi:10.1177/0192513X06287185.

Pelletier, D. (2015). The diffusion of cohabitation and children's risks of family dissolution. Paper presented at the IUSSP International seminar on Union breakdown and repartnering around the world. Montreal, 4-6 May 2015.

Royston, P. and Lambert, P.C. (2011). Flexible parametric survival analysis using Stata: Beyond the Cox model. College Station: Stata Press.

Sander, W. (1993). Catholicism and marriage in the United States. Demography 30(3): 373-384. doi:10.2307/2061646.

Schulz, S. (2009). Intergenerational transmission of divorce and growing up in stepfamilies: Does the transmission of divorce affect stepchildren as well? Zeitschrift für Familienforschung 21(1): 5-29.

Teachman, J.D. (2002). Stability across cohorts in divorce risk factors. Demography 39(4): 331-351. doi:10.1353/dem.2002.0019.

Trovato, F. (1998). Pressat's index of divorce for the Canadian provinces. In: Contributions to family demography: Essays in Honour of Dr. Wayne W. McVey, Jr. Edmonton: Department of Sociology, University of Alberta: 219-234.

Trovato, F. (2000). The probability of divorce in Canada, 1981-1995. Canadian Studies in Population 27(1): 231-238.

Vaaler, M.L., Ellison, C.G., and Powers, D.A. (2009). Religious influences on the risk of marital dissolution. Journal of Marriage and Family 71(4): 917-934. doi:10.1111/j.1741-3737.2009.00644.x.

Wolfinger, N.H. (1999). Trends in the intergenerational transmission of divorce. Demography 36(3): 415-420. doi:10.2307/2648064.

Wolfinger, N.H. (2000). Beyond the intergenerational transmission of divorce: Do people replicate the patterns of marital instability they grew up with? Journal of Family Issues 21(8): 1061-1086. doi:10.1177/019251300021008006. 
Wolfinger, N.H. (2003). Family structure homogamy: The effects of parental divorce on partner selection and marital stability. Social Science Research 32(1): 80-97. doi:10.1016/S0049-089X(02)00014-5.

Wolfinger, N.H. (2011). More evidence for trends in the intergenerational transmission of divorce: A completed cohort approach using data from the General Social Survey. Demography 48(2): 581-592. doi:10.1007/s13524-011-0025-4.

Wu, Z. and Balakrishnan, T.R. (1995). Dissolution of premarital cohabitation in Canada. Demography 32(4): 521-532. doi:10.2307/2061672. 


\section{Appendix}

D. R. Cox introduced the model that now bears his name as a way to avoid imposing the choice of a parametrised statistical distribution for, as he writes it, the "nuisance function $\lambda_{0}(t)$ " of the equation of a time-to-event model (Cox 1972: 190). The Cox model replaces the parametrised statistical distribution of a conventional regression model with the product-limit estimator of the survivor function shown by Kaplan and Meier (1958: 475) to be "the one for which the sample likelihood is a maximum," which means that it is the best possible estimator of the true survivor function from the perspective of maximum likelihood theory. For this reason, the Cox model is the best choice if the researcher focuses on the effects of the independent variables and truly regards the survivor function and its associated hazard function - as nothing but a nuisance and, of course, if the various assumptions of the model are respected, among which proportionality and the absence of unobserved heterogeneity are the most important.

The product-limit estimate of the survivor function is easily graphed as a 'stairway' function, but it is not easy to interpret: By definition, the survivor function is monotonically decreasing. This is a drawback when the research is not uniquely focused on the effects of the independent variables but is also interested in the relation between hazard and time, i.e., the 'baseline' hazard function or, using Cox's notation, $\lambda_{0}(t)$. Researchers may be interested in the hazard function because it provides valuable information on the process they are studying. Figure 1, for instance, shows that the shape of the hazard function of breakdown changes dramatically across cohorts. There is no real way to 'see' the hazard function when using the Cox model. Being able to draw the curves from Figure 1 and Figure 2, and thus being able to comment on these hazard functions, is the reason we use the Royston-Parmar model.

Originally, a spline is a flexible strip of material used in drawing curves. The word is used in statistical modelling to name a parametrisation technique in which a nonmonotonic relationship is 'cut' into a series of pieces, each having its own increasing or decreasing parameter (or set of parameters). An equation using linear splines is similar to what is known in survival analysis as a constant piecewise model, except that within each piece, the hazard is increasing or decreasing linearly -i.e., a single parameter multiplies the value of the independent variable - with respect to the independent variable (duration in hazard models, any continuous independent variable in other contexts). Cubic splines models are similar to piecewise models but use third-degree polynomials within each piece. They have been developed in computer-assisted design to model sophisticated curves. The RoystonParmar model uses cubic splines to parametrise the relationship between hazard and duration in an otherwise proportional model. It can thus accommodate nonmonotonic hazard functions and allows graphing them while retaining the ease of interpretation of the Cox model. As in the Cox model, the survivor function of Royston-Parmar models does 
not follow a conventional theoretical statistical distribution. The survivor function of Royston-Parmar models will always be second to that of the product-limit estimator as an estimate of the true survivor function. However, given that most social phenomena have a nonmonotonous hazard function, it will be closer to the true survivor function than any conventional theoretical statistical distribution.

As stated at the end of section 1, one of the objectives of this article is to analyse the hazard of breakdown of marriage and of unmarried cohabitation simultaneously in a context where unmarried cohabitation is replacing marriage as the way to enter into the first union, and marriage becomes an optional second step for most couples.

This is a thorny problem because the baseline hazard functions are different for marriage and unmarried cohabitation and because some couples begin living together without getting married and get married later. A simple solution would have been to estimate different baseline functions, one for couples who got married from the onset, one for those who started living together without being married, and one for those who get married after having started to live together. In survival analysis lingo, this would have defined three strata, with the additional feature that people who start living together unmarried move from the 'unmarried' to the 'married after having lived together' stratum.

Unfortunately, we already use strata to estimate different baseline hazard functions for each cohort. Using stratification to model the effect of the type of union would have led to equations having 15 baseline hazard functions rather than five. A more parsimonious strategy was to assume the difference between the hazard functions of each type of union to be the same across cohorts, which allowed keeping the number of strata to five. Given that the difference between the baseline hazards of the three types of union varies according to the duration of the union, we modelled this difference as time-varying, each couple being allowed to move from the 'unmarried cohabitation' to the 'marriage after cohabitation' category as they would have been allowed to do if we had used time-varying strata. The results from this parametrisation of the type of union are reported in column 5 of Table 3.

In the equation reported in column 5, the differences between cohorts reported in Figure 1 are 'decomposed' in two parts: differences between cohorts and differences between types of union. Figure 2 and 3 depict this decomposition: Figure 2 reports the 'baseline' hazard functions, i.e., that of marriage within each cohort, and Figure 2, the difference between the hazard functions of the three types of union within each cohort. This seemed the best way to illustrate the solution we used to tackle the methodological problem we were faced with.

We do not report the coefficients of the cubic spline parametrisation of the cohort strata. There are 15 of them for each equation, and some columns of Table 3 report results from many different equations. These coefficients are not easy to interpret: The information they carry is better understood using it to graph the relation between hazard and time. 